\title{
Effectiveness of a Silicon-Based Root Canal Sealer for Filling of Simulated Lateral Canals
}

\author{
João Vicente Baroni BARBIZAM ${ }^{1}$ \\ Matheus SOUZA ${ }^{1}$ \\ Doglas CECCHIN ${ }^{1}$ \\ Jakob DABBEL ${ }^{2}$ \\ ${ }^{1}$ Department of Endodontics, University of Passo Fundo, Passo Fundo, RS, Brazil \\ ${ }^{2}$ Department of Endodontics, University of North Carolina, Chapel Hill, NC, USA
}

\begin{abstract}
The purpose of this in vitro study was to evaluate the ability of a silicon-based root canal sealer, compared to zinc oxide and eugenol and an epoxy resin-based sealers, for filling of simulated lateral canals. Thirty extracted single-rooted human teeth were selected, conventional access was made and the working length was established $1 \mathrm{~mm}$ from the apical foramen. Three simulated lateral canals, one in each root third (coronal, middle and apical) were prepared in both the mesial and distal surfaces of each tooth using a size 15 reamer adapted to a low-speed handpiece. Each root canal was instrumented using ProTaper rotary files up to file F3 at the working length, and then irrigated with $2.5 \% \mathrm{NaOCl}$ followed by EDTA. The teeth were assigned to 3 groups $(\mathrm{n}=10)$, according to the root canal sealer: Roeko Seal (Group 1), Sealer 26 (group 2) and Grossman's sealer (Group 3). Gutta-percha cold lateral condensation technique was performed in all groups. Postoperative radiographs were taken and the images were projected for evaluation of the quality of lateral canal filling. Data were submitted to statistical analysis by Kruskal Wallis test at $5 \%$ significance level. The results showed that Grossman's sealer filled a larger number of lateral canals than Roeko Seal $(\mathrm{p}<0.05)$ and Sealer $26(\mathrm{p}<0.01)$. It may be concluded that Roeko Seal silicone-based root canal sealer was not as effective as the Grossman's sealer for filling of simulated lateral canals. The lateral canals localized in the apical third of the root were more difficult to be filled.
\end{abstract}

Key Words: Endodontics, root canal sealers, lateral canals.

\section{INTRODUCTION}

It has been shown that a considerable number of teeth have accessory root canals, particularly in the apical third of the root (1), which extend from the root canal space to the apical and periapical regions. These canals represent an important route for bacterial leakage that can lead to root canal treatment failure. Several studies have reported endodontic success after obturation of lateral canals $(2,3)$. Therefore these variations of root canal anatomy might have a significant impact on the treatment outcome.

The ability of the endodontic sealers to properly fill accessory canals has been investigated by several authors (2-6). The scopes of these studies have included different filling techniques (4), the consistence of root canal sealers (5) and the influence of intracanal medications (6).

The properties of a silicon-based root canal sealer, market under the commercial brand Roeko Seal (Roeko, Langenau, Germany) have been recently investigated. It has been shown that this endodontic sealer provides a good film thickness (7) and allows only little apical leakage $(8,9)$. Several studies have described the biological behavior of Roeko Seal by demonstrating lack of cytotoxicity (10) or mutagenic effects (10-12). Nevertheless, further investigations should be carried out to evaluate the clinical effectiveness of this material.

The purpose of this study was to evaluate the ability of Roeko Seal silicone-based root canal sealer to fill simulated lateral canals in comparison to Grossman's sealer and Sealer 26, a zinc oxide and eugenol sealer and an epoxy resin-based sealer, respectively. 


\section{MATERIAL AND METHODS}

Thirty extracted single-rooted human teeth were used in this study. Conventional endodontic access was performed using a high speed diamond bur with water coolant.

Pulp chambers were irrigated with $2.5 \%$ sodium hypochlorite $(\mathrm{NaOCl})$ and the pulp tissue, if present, was removed using a size 25 Hedstroem hand file (Dentsply/Maillefer, Ballaigues, Switzerland). The root length was established by introducing a size $10 \mathrm{~K}$-type file (Dentsply/Maillefer) into the canal until its tip was visible at the apical foramen. The working was determined by subtracting $1 \mathrm{~mm}$ from this measurement.

Three simulated lateral canals were then prepared on the mesial and distal surfaces of each tooth, as described by Goldberg et al. (4). All teeth were instrumented according to a crown-down technique using ProTaper nickel-titanium rotary files (Dentsply/ Maillefer) up to a F3 file, until reaching the working length. The canals were irrigated with $2 \mathrm{~mL}$ of $2.5 \%$ sodium hypochlorite at each change of file. After instrumentation, the smear layer was removed using 5 $\mathrm{mL}$ of EDTA (Pulpdent, Watertown, MA, USA), followed by $5 \mathrm{~mL}$ of saline (Abbot, Chicago, IL, USA) as a final flush.

The root canals were dried with paper points and the teeth were assigned to 3 groups ( $n=10)$, according to the root canal sealer used. Group 1 was filled with a silicone-based root canal sealer (Roeko Seal; Roeko); Group 2 was filled with an epoxy resin-based root canal sealer (Sealer 26; Dentsply Indústria e Comércio Ltda; Petrópolis, RJ, Brazil); and Group 3 was filled with a zinc oxide and eugenol-based root canal sealer, Grossman's Sealer (Endo fill; Dentsply Indústria e Comércio Ltda).

All root canal sealers were mixed according to manufacturer's instructions, except for Grossman's Sealer that was mixed according to Pécora et al. (5). The sealers were then introduced into the root canals using master gutta- percha cones (Dentsply/Maillefer) and cold lateral condensation of accessory gutta-percha points was performed.

Buccolingual radiographs were taken of all groups using the same exposure settings for each specimen. The radiographs were developed and fixed using the same time and temperature settings for all radiographs. The radiographs were then projected and magnified 20 times, subjected to blind examination and each lateral canal was ranking score scale, as follows; unfilled (score 1); partially filled (score 2); and filled (score 3). Data were recorded and analyzed statistically by Kruskal Wallis test at $5 \%$ significance level.

\section{RESULTS}

There were statistically significant differences $(p<0.05)$ between the sealers regarding their ability to effectively fill the lateral canals. The Grossman's Sealer yielded better filling Roeko Seal $(\mathrm{p}<0.05)$ and Sealer 26 $(\mathrm{p}<0.01)$. The number of lateral canals filled by according to the sealer is given on Table 1 . The number of lateral canals filled according to the location of the lateral canals is given on Table 2. Representative radiographs of all groups are shown on Figure 1.

\section{DISCUSSION}

The presence of lateral canals is a constant challenge to endodontists. A non-sealed lateral canal

Table 1. Number and percentage (\%) of filled, partially filled and unfilled lateral canals according to the tested root canal sealers.

\begin{tabular}{lcccr}
\hline Sealer & Number of lateral canals & Filled & Partially filled & Unfilled \\
\hline Grossman & 60 & $47(78.3 \%)$ & $11(18.3 \%)$ & $2(3.3 \%)$ \\
Roeko Seal & 60 & $34(56.6 \%)$ & $23(38.3 \%)$ & $3(5.0 \%)$ \\
Sealer 26 & 60 & $26(43.3 \%)$ & $22(36.6 \%)$ & $12(20 . \%)$ \\
\hline
\end{tabular}

Table 2. Number and percentage (\%) of filled, partially filled and unfilled lateral canals according to the different root thirds.

\begin{tabular}{lcccc}
\hline Location & Number of lateral canals & Filled & Partially filled & Unfilled \\
\hline Coronal & 60 & $49(81.6 \%)$ & $10(16.6 \%)$ & $1(1.6 \%)$ \\
Middle & 60 & $39(65.0 \%)$ & $18(30.0 \%)$ & $3(5.0 \%)$ \\
Apical & 60 & $19(31.6 \%)$ & $28(46.6 \%)$ & $13(21.6 \%)$ \\
\hline
\end{tabular}


allows a two-way passage of bacteria and tissue degradation products between the root canal space and the periodontal tissues (13). In an attempt to produce experimental conditions as closer as possible to the clinical reality (canals with diameter of approximately $150 \mu \mathrm{m})(14)$, we created lateral canals using a size 15 reamer adapted to a low-speed handpiece, following the methodology proposed by Goldberg et al. (4) and modified by Pécora et al. (5).

In order to avoid the presence of unfilled spaces, the instrumented root canals should be flushed with an irrigating solution that is able to dissolve organic tissues and remove the smear layer. Sodium hypochlorite followed by EDTA has been used for this purpose, acting on the spaces that endodontic instruments cannot reach.

Weine (14) reported that the filling technique does not have an important effect on obturation of lateral canals. On the other hand, Goldberg et al. (4) demonstrated that thermoplasticized gutta-percha techniques are more effective for filling lateral canals than cold lateral condensation. In the present study, cold lateral compaction of gutta-percha was the technique of choice because it has been widely used and may be considered as a control technique. In addition, the goal of this study was to evaluate the sealers not the filling techniques.

Several properties of root canal sealers have been studied, such as setting time, solubility, disintegration, film thickness and dimensional changes after setting (15). Among the ideal properties of root canal sealers,

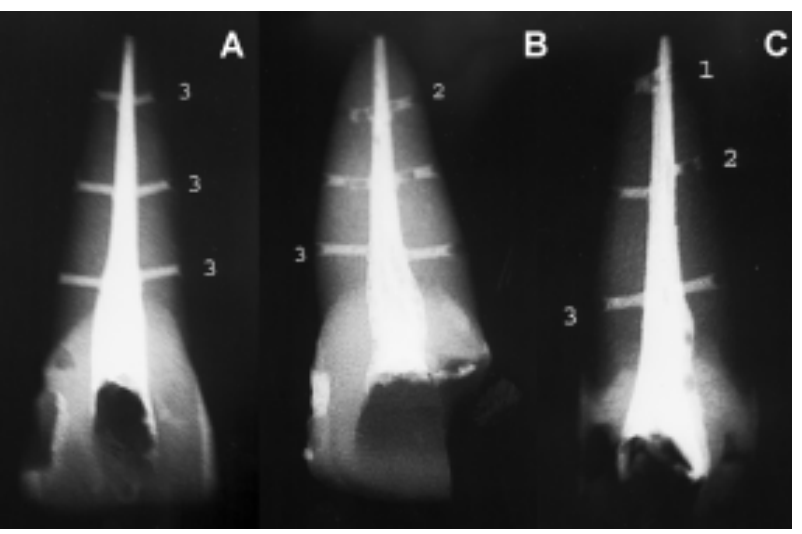

Figure 1. Radiograph of the teeth filled with Grossman's Sealer (A), Roeko Seal (B) and Sealer 26 (C). The numbers near to the roots are examples of the scores given to each lateral canal of different groups. one of the most important is the ability to flow enough to completely fill the root canal space. Pécora et al. (5) demonstrated that zinc oxide eugenol based sealers require a correct powder-to-liquid ratio in order to present a consistence flowable enough to entirely fill the root canal. The present study followed the recommendations given by Pécora et al. (5) when using Grossman's sealer. Our results were consistent with those of that study (5), which indicates that the ability of Grossman's sealer to fill lateral canals if correctly mixed. The performance of the Grossman's sealer was superior to that of Roeko Seal and Sealer 26, which failed to fill completely the lateral root canals as well as the Grossman's sealer. Further studies should be conducted to investigate other properties of this recent root filling material.

In agreement with Goldberg et al. (6), the present study showed the difficulty of filling lateral canals in the apical root third. For all tested materials, the number of non-filled or partially filled lateral canals was larger in the apical third. This finding is clinically important because it is well known that there is a greater percentage of lateral canals $t$ in the apical third of the root.

Based on the results obtained and within the limitations of the methodology, it may be concluded that Roeko Seal silicone-based root canal sealer was not as effective as the Grossman's sealer for filling of simulated lateral canals. The lateral canals localized in the apical root third were more difficult to be filled.

\section{RESUMO}

O objetivo desse estudo in vitro foi avaliar a capacidade de um cimento a base de silicone, em obturar canais laterais simulados, em comparação a um cimento à base de oxido de zinco e eugenol e um cimento resinoso. Trinta dentes humanos unirradiculares extraídos foram selecionados, a abertura coronária foi feita e o comprimento de trabalho foi determinado $1 \mathrm{~mm}$ aquém do forame apical. Foram confeccionados três canais laterais, um em cada terço radicular, em ambas as faces mesial e distal da raiz, usando um alargador 15 acoplado a um contra-ângulo em baixa rotação. Os canais foram instrumentados com sistema Protaper até a lima F3, sob irrigação com hipoclorito de sódio a 2,5\%, seguido de EDTA. Os dentes foram divididos em 3 grupos $(\mathrm{n}=10)$ e obturados com o cimento de Grossman, RoekoSeal ou Sealer 26, pela técnica da condensação lateral da gutta-percha. Foram feitas tomadas radiografias pós-operatórias, projetadas em aumentos de 20X para avaliação da qualidade das obturações. Os dados foram analisados estaticamente pelo teste de Kruskal Wallis com nível de significância de $5 \%$. Os resultados mostraram que o cimento de Grossman obturou um numero maior de canais laterais que o cimento RoekoSeal $(\mathrm{p}<0,05)$ e o Sealer $26(\mathrm{p}<0,01)$. Pode- 
se concluir que o cimento Roeko Seal não foi tão eficiente quanto o cimento de Grossman para o selamento de canais laterais, bem como, que os canais laterais situados no terço apical da raiz apresentaram maior dificuldade para serem obturados.

\section{ACKNOWLEDGEMENTS}

This study was supported by a grant-in-aid from CAPES (BEX 0546/05-4).

\section{REFERENCES}

1. De Deus QD. Frequency, location and direction of lateral, secondary and accessory canals. J Endod 1975;1:361-365.

2. Weine F. The enigma of the lateral canal. Dent Clin North Am 1984;28:833-852.

3. Xu G, Zhang Z. Filling of the lateral canal. Oral Surg 1984;58:221-224.

4. Goldberg F, Artaza LP, De Silvio A. Effectiveness of different obturation techniques in the filling of simulated lateral canals. J Endod 2001;27:362-364.

5. Pécora JD, Ribeiro RG, Guerisoli DM, Barbizam JV, Marchesan MA. Influence of the spatulation of two zinc oxide-eugenolbased sealers on the obturation of lateral canals. Braz Oral Res 2002;16:127-130.

6. Goldberg F, Artaza LP, De Silvio A. Influence of calcium hydroxide dressing on the obturation of simulated lateral canals. J Endod 2002;28:99-101.

7. Testarelli L, Andreassi Bassi M, Gambarini G. In vitro evaluation of five root canal sealers. Minerva Stomatol 2003;54:19-24.

8. Wu MK, Tigos E, Wesselink PR. An 18 month longitudinal study on a new silicon-based sealer, RSA Roeko Seal: A leakage study in vitro. Oral Surg, Oral Med, Oral Pathol, Oral Radiol, Endod 2002;94:499-502.

9. Cobankara FK, Adanir N, Belli S, Pashley DH. A quantitative evaluation of apical leakage of four root canal sealers. Int Endod J 2002;35:979-984.

10. Schwarze T, Leyhaunsen G, Geurtsen W. Long-term cytocompatibility of various endodontic sealers using a new root canal model. J Endod 2002;28:749-753.

11. Öztan MD, Yilmaz S, Kalayci A. A comparison of the in vitro cytotoxicity of two root canal sealers. J Oral Rehabil 2003;30:426-429.

12. Miletic I, Devic N, Aric I, Boric J, Karlovic Z, Osmak M. The cytotoxicity of Roeko Seal and AH Plus compared during different setting periods. J Endod 2005;31:301-309.

13. Harrington GW. The perio-endo question: differential diagnoses. Dent Clin North Am 1979;23:673-690.

14. Weine F. The enigma of the lateral canal. Dent Clin North Am 1984;28:833-852.

15. Versiani MA, Carvalho-Jr JR, Padilha MI, Lacey S, Pascon EA, Sousa-Neto MD. A comparative study of physicochemical properties of $\mathrm{AH}$ Plus and Epiphany root canal sealants. Int Endo J 2006;39:464-471.

16. Mendonca SC, de Carvalho Júnior JR, Guerisoli DMZ, Pécora JD, de Sousa-Neto MD. In vitro study of the effect of aged eugenol on the flow, setting time and adhesion of Grossman root canal sealer. Braz Dent J 2000;11:71-78.

Accepted September 4, 2006 